\title{
PETER NICHOLAS TARLING: A TRIBUTE
}

\author{
Ooi Keat Gin* \\ Asia-Pacific Research Unit (APRU), School of Humanities, \\ Universiti Sains Malaysia, Penang, Malaysia \\ email:kgooi@hotmail.com
}

Published online: 15 July 2017

To cite this article: Ooi, K. G. 2017. Peter Nicholas Tarling: A tribute. International Journal of Asia Pacific Studies 13 (2): 161-177, https://doi.org/10.21315/ ijaps2017.13.2.8

To link to this article: https://doi.org/10.21315/ijaps2017.13.2.8

Nicholas Tarling is one of the foremost historians of the role of the British in Southeast Asia during the nineteenth and twentieth centuries. Well established in his field of expertise specifically focusing on British policy in and towards Malaya / Malaysia, Indonesia, Siam / Thailand and Myanmar (Burma), he has authored and edited close to 40 books including the two volume The Cambridge History of Southeast Asia (Cambridge, 1992), and more than 90 scholarly journal articles in an academic career spanning more than half a century.

Nick, as he is affectionately known, is the quintessential scholar: a consummate researcher and a prolific writer. Poring through literally miles of archival documents is but second nature to him; likewise putting pen to paper for his findings, analysis, interpretations, thoughts and opinions to churn out manuscript after manuscript for publication. Apart from history, his forte, Nick wrote on higher education and on the performing arts (music and theatre).

Born on 1 February 1931 in Iver, south Buckinghamshire, England, Peter Nicholas Tarling is the second child of Ronald William Tarling (190167) and Doris Nevill Tarling, née Bibbye (1903-2002). Nick's elder brother, Michael, is four years his senior, and his younger siblings are Francis (b. 1936), Julian (b. 1939), and Fiona (b. 1940). He had his secondary education at St Albans School. At the age of 18 he entered Christ's College, Cambridge where he graduated in 1952 with a BA, and subsequently obtained the MA and $\mathrm{PhD}$ in 1956 under the guidance of Dr Victor Purcell, who had long served as 
a colonial officer in the Malayan Civil Service (MCS). His doctoral thesis was 'British Policy towards the Dutch and Native Princes in the Malay Archipelago, 1824-1871'.

Nick began his academic career as an assistant at the Royal Historical Society, London (1956-7). Thereafter he left England for Australia where he took up appointment as Lecturer, than Senior Lecturer, in History at the University of Queensland, Brisbane (1957-65). Moving further afield he became Associate Professor of History at the University of Auckland, Auckland (1965-8), and subsequently Professor of History (1968-97). Upon his retirement in 1997 he was appointed Emeritus Professor at the University of Auckland. Made a Fellow of the university's New Zealand Asia Institute (NZAI) in 1997, he was its Acting Director in 2001. In 2002 he was Acting Director of the university's International Office. Following his retirement he spent half a year (1997) as visiting Professor at Universiti Brunei Darussalam. Between 1997 and 2002 he was Honorary Professor at the Centre for SouthEast Asian Studies, University of Hull. He is a Fellow of the Borneo Research Council.

Without over exaggeration, Nick served on practically every committee and held every position at the University of Auckland including dean, deputy vice-chancellor and acting vice-chancellor. His more than three decades service saw him chairing scores of university committees, elected to the Senate, and as the university's Public Orator.

Off the University of Auckland campus Nick served on three University Grants Committee sub-committees - the Overseas Students Admissions Committee, the Scholarships Committee, and the Curriculum Committee - and also on the University's Entrance Board. He also served on several committees at the ministerial and departmental level in the field of secondary and tertiary education. He was active in the New Zealand Vice-Chancellors Committee and contributed as a member or chair in various subcommittees.

Whilst at Brisbane and Auckland Nick conducted courses on Southeast Asian history at the undergraduate and postgraduate levels, and supervised a string of MA and $\mathrm{PhD}$ candidates. He also taught modern European history focusing on the causal factors leading to the outbreak of World War I (191418). Late nineteenth and early twentieth century modern Japanese history was one of his other teaching specialities.

For many years Nick served as a member on the editorial boards of academic journals: Journal of Southeast Asian Studies (Singapore), Itinerario (Leiden), Modern Asian Studies (Cambridge), The International History Review (Vancouver), Borneo Research Bulletin (Portland), and the e-journal 
International Journal of Asia-Pacific Studies (Penang). For nearly three decades he was associate editor of New Zealand Journal of History (1967-96).

As founder-chairman of the Auckland History Teachers Association (1971-4), Nick was instrumental in uniting secondary and tertiary history teachers under one umbrella organization. He was reappointed to the chair in 1979-81 and 1983-5. He was founder-president of the New Zealand Asian Studies Society (1972-8) with reappointments in later years. In 1995 he was made a life member.

In organizing academic conferences Nick was a veteran. He chaired the organizing committee for the inaugural New Zealand Studies Conference in 1974, 1979, 1987, and 1995. He was organizing chairman of the 49th Congress of the Australian and New Zealand Association for the Advancement of Science (ANZAAS) in Auckland, January 1979 where some 4200 delegates participated. In 1983 he chaired the University of Auckland's centenary celebrations.

While in Brisbane Nick was a member of the University of Queensland Staff Association. When in Auckland (1968-9) he was president of the Auckland University Senior Common Room. He was involved with the Association of University Teachers (AUTNZ) from 1965 acting as national president (19701 and 1973-4), and led a delegation to visit the People's Republic of China (PRC) in 1974.

From its foundation in 1971 Nick was a member of the Auckland Teachers Colleges Council until 1980, and also served on various committees of the now defunct North Shore Teachers' College. He also contributed to adult and continuing education conducting classes in history in Brisbane and in Auckland.

Outside academic pursuits on and off campus Nick's love of music and the theatre witnessed his involvement in the performing arts. In Brisbane he joined the Twelfth Night Theatre and the Queensland Symphony Orchestra Advisory Committee. Ever the teacher he offered courses and organized seminars on opera in Auckland, and annually led a study group to the Australian Opera in Sydney. Furthermore Nick served as academic leader of opera tours to Europe (1997, 1999, 2001 and 2006).

Nick was active on the stage in Auckland with his involvement in staffstudent groups like the University Theatre Workshop and the revue club as well as off-campus organizations like the Mercury Theatre (its trustee, 197892) and Howick Little Theatre. He celebrated his 100th production in 1983. In recent years he has played roles such as Sir in The Dresser and C. S. Lewis in Shadowlands. He has participated in some 20 programmes of music and 
dramatic readings, performed publicly in Auckland, and for Elderhostel groups.

While in Brisbane Nick was involved in broadcasting on Australian Broadcasting Corporation (ABC). When in Auckland he spoke on radio and television on current affairs, historical, musical and literary topics and issues; his Sunday morning 'Opera Hour' ran for an astonishing fifteen years. The Auckland Philharmonia benefited from his pre-concert talks.

Nick served as a trustee for the Auckland Opera Trust. He was also for many years the chairman of the Friends of the New Zealand Symphony Orchestra. In 1975 he was appointed to the Queen Elizabeth II Arts Council; later became its deputy chairman and chaired its music panel and its committees on regional development, orchestras and operas. The Minister of Internal Affairs made him chairman of the Northern Regional Arts Council and a member of the Ministry's Cultural Facilities Committee that handed out Lottery funds for construction, renovation and refurbishing schemes. He also chaired the New Zealand Broadcasting Council Orchestral Advisory Committee (1976-8) that was responsible for the New Zealand Symphony Orchestra, the Schola Musica, and the National Youth Orchestra. He headed the executive committee of the Symphonia of Auckland between 1978 and 1980, was a trustee of Auckland Opera / Opera New Zealand till 1997, and a member of the North Shore Theatre Trust (1995-9).

Nick continues to fascinate with his involvement in the community. While in Brisbane he was a member of the Aboriginals' Advancement League, an activist group promoting native Australian rights. In New Zealand although not a Mason, he was patron of the Masonic Lodge of the Liberal Arts. He also assisted the Masonic Education Trust.

Peter Nicholas Tarling was a recipient of the Queen's Jubilee Medal in 1977. He was made a Member of the New Zealand Order of Merit (MNZM) in 1996 shortly before his retirement. His alma mater the University of Cambridge awarded him Doctor of Letters (Litt.D) in 1974. The University of Auckland that he served for more than three decades honoured him with an Honorary Doctor of Letters (Hon. Litt.D) in 1996. He was elected Fellow of the Royal Asiatic Society (1963) and Fellow of the Royal Historical Society (1963).

Nick travelled extensively throughout Southeast Asia with repeated visits particularly to Malaysia and Singapore as well as to Brunei, Myanmar and Cambodia. On a Carnegie grant he spent three months in 1963 in Canada and the United States. He delivered papers in almost all the International Association of Historians of Asia (IAHA) conferences, delivered addresses at Kyoto University, the Institute of Oriental Studies in Moscow, the Institute 
of South Asia in Heidelberg, and in various other institutes and centres. The National Institute of Education, Nanyang Technological University, Singapore appointed him external assessor in 2005.

As Emeritus Professor, Nick is currently attached to the New Zealand Asia Institute and continues to undertake research, writing, and publishing as well as being active in the scores of recreational and community interests that he has nurtured over the years.

\section{PUBLISHED WORKS BY NICHOLAS TARLING}

Nick is a tireless researcher and diligent and consummate writer despite his other undoubtedly heavy administrative commitments in his pre-retirement days. Some time back I remembered requesting him for an essay or two and within a fortnight he delivered the pieces he had promised much to my (any editor's) unabashed delight. He religiously keeps to deadlines and submits his manuscripts according to required house-styles of publishers and journals hence allowing editors to have longer coffee breaks - perhaps a scone or doughnut or two - to savour. Over more than five decades of dedicated scholarship, the following pages record his prolific output that has contributed to our greater understanding of events and issues.

\section{Books Authored}

British Policy in the Malay Peninsula and Archipelago, 1824-1871. First published in Journal of the Malayan Branch of the Royal Asiatic Society, 30, 3 (October 1957); reprinted in Oxford in Asia Historical Reprints, Kuala Lumpur, 1969.

Anglo-Dutch Rivalry in the Malay World, 1780-1824. St Lucia: University of Queensland Press; London and New York: Cambridge University Press, 1962.

Piracy and Politics in the Malay World: A Study of British Imperialism in NineteenthCentury Southeast Asia. Melbourne: F. W. Cheshire; Singapore: Donald Moore, 1963; Kraus reprint, Nendeln, 1978.

A Concise History of Southeast Asia. New York: Praeger; London: Pall Mall; Singapore: Donald Moore, 1963. Republished as Southeast Asia Past and Present, Melbourne: F. W. Cheshire, 1966.

Britain, the Brookes and Brunei. Kuala Lumpur: Oxford University Press, 1971. Imperial Britain in Southeast Asia. Kuala Lumpur: Oxford University Press, 1975.

Sulu and Sabah: A Study of British Policy towards the Philippines and North Borneo. Kuala Lumpur: Oxford University Press, 1978.

The Burthen, the Risk and the Glory: A Life of Sir James Brooke. Kuala Lumpur: Oxford University Press, 1982. 
'The Fourth Anglo-Burmese War': Britain and the Independence of Burma. Gaya: Centre of South East Asian Studies, 1987.

The Sun Never Sets: An Historical Essay on Britain and Its Place in the World. Delhi: Stirling, 1987.

The Fall of Imperial Britain in South East Asia. Singapore: Oxford University Press, 1993. (with Ruth Butterworth) A Shakeup Anyway. Government and Universities in New Zealand in a Decade of Reform. Auckland: Auckland University Press, 1994.

Britain, Southeast Asia and the Onset of the Pacific War. Cambridge: Cambridge University Press, 1996; paperback, 2006.

Nations and States in Southeast Asia. Cambridge: Cambridge University Press, 1998.

Britain, Southeast Asia and the Onset of the Cold War. Cambridge: Cambridge University Press, 1998.

Auckland: The Modern University. Auckland: Auckland University Press, 1999.

Professionals and Unionists: A History of the Association of University Staff, 1923-98. Wellington: Association of University Staff (AUS), 2000.

Historians and Southeast Asian History. Auckland: New Zealand Asia Institute, 2000.

Southeast Asia: A Modern History. Melbourne: Oxford University Press, 2001.

(with Margaret Lamb) From Versailles to Pearl Habor. The Origins of the Second World

War in Europe and Asia. Basingstoke: Palgrave, 2001.

A Sudden Rampage. The Japanese Occupation of Southeast Asia, 1941-1945. London: Hurst, 2001.

Imperialism in Southeast Asia. A Fleeting Passing Phase. London; Routledge, 2001.

On and Off: Opera in Auckland, 1970-2000. Palmerston North: Dunmore, 2002.

International Students in New Zealand. The Making of Policy since 1950. Auckland: New Zealand Asia Institute, 2004.

Nationalism in Southeast Asia. If the People are with Us. London: RoutledgeCurzon, 2004. Imperialism in Asia. An Essay. Auckland: New Zealand Asia Institute, 2005.

Britain, Southeast Asia and the Impact of the Korean War. Singapore: Singapore University Press, 2005.

Regionalism in Southeast Asia. To Foster the Political Will. London and New York: Routledge, 2006.

Wit, Eloquence and Commerce. A History of Auckland's Mercury Theatre. Auckland: Connacht Books, 2007.

(with Wilf Malcolm) A Crisis of Identity? The Mission and Management of New Zealand Universities. Wellington: Dunmore, 2007.

\section{Books Edited}

China and Its Place in the World. Auckland: Paul, 1967.

(with Jerome Ch'en) Studies in the Social History of China and South-East Asia. Cambridge: Cambridge University Press, 1970.

Australia, New Zealand and Southeast Asia. Special issue of Journal of Southeast Asian Studies, 2, 1 (March 1971).

Mrs Pryer in Sabah: Diaries and Papers. Auckland: Centre for Asian Studies, 1989. 
The Cambridge History of Southeast Asia, 2 vols. Cambridge University Press, 1992; 4 vols. Paperback, with new introductions, 1999. Chinese translation: Yunnan People's Publishing House, 2003.

Singapore and the Singaporeans since 1819. Auckland: Centre for Asian Studies, 1992.

The Journal of Henry Burney in the Capital of Burma, 1830-1832. Auckland: New Zealand Asia Institute, 1995.

Auckland Minds and Matters. Auckland: The University of Auckland, 2003.

Corruption and Good Governance in Asia. London and New York: Routledge, 2005.

Historians and their Discipline: The Call of Southeast Asian History. Kuala Lumpur: Malaysian Branch of the Royal Asiatic Society (MBRAS), 2007.

\section{Books for Schools}

Mao and the Transformation of China. Auckland: Heinemann, 1977.

Sukarno and Indonesian Unity. Auckland: Heinemann, 1977.

\section{Articles and Chapters}

'The Relationship between British Policies and the Extent of Dutch Power in the Malay Archipelago', Australian Journal of Politics and History, 4, 2 (November 1958), pp. 179-92.

'The Annexation of the Cocos-Keeling Islands', Historical Studies, 8, 32 (May 1959), pp. 400-04.

'Siam and Sir James Brooke', Journal of Siam Society, 48, 2 (November 1960), pp. 43-72.

'Pirates and Convicts: British Interest in the Andaman and Nicobar Islands in the midcentury', Journal of Indian History, 37, 3 (December 1960), pp. 505-26.

'From Machiavelli to Soedjatmoko', Satadal (Melbourne), 3 (1961), pp. 19-24.

'Towards West Irian?', World Review (Brisbane), 1, 1 (March 1962), pp. 17-26.

'British Policy in Malayan Waters in the Nineteenth Century', in K. G. Tregonning, ed., Papers on Malayan History, Singapore: Oxford University Press, 1962, pp. 73-88.

'Intervention and Non-intervention in Malaya', Journal of Asian Studies, 21, 4 (August 1962), pp. 523-7.

'The Mission of Sir John Bowring to Siam', Journal of Siam Society, 50, 2 (December 1962), pp. 91-118.

'The Kim Eng Seng', Journal South East Asian History, 4, 1 (March 1963), pp. 103-114.

'The Palmer Loans', Bidragen tot de Taal-, Land- en Volkenkunde, 119, 2 (1963). Reprinted in D. P. Cook, ed., Questioning the Past, St Lucia: University of Queensland Press, 1972, pp. 96-116.

'Sir James Brooke and Brunei', Sarawak Museum Journal, 11, 21-22 (New Series) (JulDec 1963), pp. 1-12.

'Some Aspects of British Trade in the Philippines in the Nineteenth Century', The Journal of History (Manila), 11, 3 \& 4 (Sep-Dec 1963), pp. 287-327.

'Some Comments on South East Asian Studies in Australia', Southeast Asian Studies (Kyoto), 2, 2 (December 1964), pp. 99-103. 
'The Prince of Merchants and the Lion City', Journal of the Malaysian Branch of the Royal Asiatic Society, 37, 1 (1964), pp. 20-40.

'Harry Parkes' Negotiations in Bangkok in 1856', Journal of Siam Society, 53, 2 (July 1965), pp. 153-80.

'The Study of Asia', The University of Auckland Gazette, 7, 2 (August 1965), pp. 1-4.

'Vietnam: Some Historical Viewpoints', World Review, 4, 3 (September 1965), pp. 3-12.

'Consul Farren and the Philippines', Journal of the Malaysian Branch of the Royal Asiatic Society, 37, 2 (1965), pp. 258-73.

'The Superintendence of British Interests in Southeast Asia in the Nineteenth Century', Journal of Southeast Asian History, 7, 1 (March 1966), pp. 97-110.

'British Relations with Vietnam, 1822-1858', Journal of the Malaysian Branch of the Royal Asiatic Society, 39, 1 (1966), pp. 19-51.

'Asian Studies in New Zealand', Newsletter of the Association of Asian Studies, 11, 1 (May 1967), pp. 55-57.

'China, Its Tributaries and the West', in N. Tarling, ed., China and Its Place in the World, Auckland: Paul, 1967, pp. 1-10.

'The Entrepot at Labuan and the Chinese', in J. Ch'en and N. Tarling, eds., Studies in the Social History of China and South-East Asia, Cambridge: Cambridge University Press, 1970, pp. 355-73. Reprinted in Sabah Society Journal, 5, 2 (December 1970), pp. 101-16.

'Britain and Brunei in the Nineteenth Century', Journal of the University of Singapore Historical Society (July 1970), pp. 12-18.

'Britain and Sarawak in the Twentieth Century: Raja Charles, Raja Vyner and the Colonial Office, Journal of the Malaysian Branch of the Royal Asiatic Society, 43, 2 (1970), pp. 22-52.

'Sir Cecil Clementi and the Federation of British Borneo', Journal of the Malaysian Branch of the Royal Asiatic Society, 44, 2 (1971), pp. 1-34.

'Southeast Asia in Australasian Universities', Journal of Southeast Asian Studies, 2, 1 (March 1971), pp. 78-85.

'Introduction' to reprint of John Anderson, Mission to the East Coast of Sumatra in 1823. Kuala Lumpur: Oxford University Press, 1972.

'Borneo and British Intervention in Malaya', Journal of Southeast Asian Studies, 5, 2 (September 1974), pp. 159-65.

'Asian Studies and New Zealand Universities', Newsletter of the New Zealand Asian Studies Society, 1 (December 1974), pp. 4-11.

'The Bowring Mission: The Mellersh Narrative', Journal of Siam Society, 63, 1 (January 1975), pp. 105-26.

'Rizal, Aguinaldo and North Borneo', New Zealand Journal of History, 9, 2 (October 1975), pp. 179-83.

'Spenser St John and his "Life in the Forests of the Far East"', Sarawak Museum Journal, 23, 44 (Jul-Dec 1975), pp. 293-305.

'Some Notes on the Historiography of British Borneo', in C. D. Cowan and O. W. Wolters, eds., Southeast Asian History and Historiography. Essays presented to D. G. E. Hall, Ithaca and London: Cornell University Press, 1976, pp. 285-95. 
'King Prajadhipok and the Apple Cart', Journal of Siam Society, 64, 2 (July 1976), pp. 1- 38. 'History and Histrionics', New Zealand Journal of History, 11, 2 (October 1977), pp. 10511.

"'When the Old Lady Dies": Britain and the Security of Netherlands India, 1939-1941', Southeast Asian Review, 2, 1 (August 1977), pp. 51-81; 3, 1 (August 1978), pp. $41-72$.

"'A Vital British Interest": Britain, Japan and the Security of Netherlands India during the Inter-War Period', Journal of Southeast Asian Studies, 9, 2 (September 1978), pp. 180-218.

'Atonement before Absolution: British Policy towards Thailand during World War II', Journal of Siam Society, 66, 1 (January 1978), pp. 22-65.

'Rice and Reconciliation: The Anglo-Thai Peace Negotiations of 1945', Journal of Siam Society, 66, 2 (July 1978), pp. 59-111.

'The Wars of British Succession', New Zealand Journal of History, 15, 12 (April 1981), pp. 24-34.

'Sir James Brooke: A New Biography. Some Comments', Sarawak Museum Journal, 29, 50 (December 1981), pp. 137-41.

"'A New and A Better Cunning": British Wartime Planning for Post-War Burma, 1942-3', Journal of Southeast Asian Studies, 13, 1 (March 1982), pp. 33-59.

"'An Empire Gem": British Wartime Planning for Post-War Burma, 1943-4', Journal of Southeast Asian Studies, 13, 2 (September 1982), pp. 310-48.

"'The Merest Pustule": The Singapore Mutiny of 1915', Journal of the Malaysian Branch of the Royal Asiatic Society, 55, 2 (December 1982), pp. 26-59.

'Lord Mountbatten and the Return of Civil Government to Burma', Journal of Imperial and Commonwealth History, 11, 2 (January 1983), pp. 197-226.

'Mat Salleh and Krani Usman', Journal of Southeast Asian Studies, 16, 1 (March 1985), pp. 46-68.

"'A Prompt Gesture of Goodwill": Anglo-Philippine Relations after the Second World War', Filipinas (Fall 1985), pp. 27-51.

'The United Kingdom and the Origins of the Colombo Plan', Journal of Commonwealth and Comparative Politics, 24, 1 (March 1986), pp. 3-34.

"'Some Rather Nubelous Capacity": Lord Killearn's Appointment in Southeast Asia', Modern Asian Studies, 20, 3 (July 1986), pp. 559-600.

"'An Attempt to Fly in the Face of the Ordinary Laws of Supply and Demand". The British and Siamese Rice', Journal of Siam Society, 75 (1987), pp. 140-86.

'What A Wonderful Thing is Metaphor', Historical News, 54 (May 1987), pp. 5-7.

'Introduction' to reprint of S. Baring-Gould and C. A. Bampfylde, A History of Sarawak under Its Two White Rajahs, Singapore: Oxford University Press, 1989.

'Malaya in British History', Journal of the Malaysian Branch of the Royal Asiatic Society, 62, 1 (1989), pp. 11-20.

'The British and the First Japanese Move into Indo-China', Journal of Southeast Asian Studies, 21, 1 (March 1990), pp. 35-65.

'St John's Biography of Sir James Brooke', Sarawak Museum Journal, 42, 62 (1990), pp. 255-76. 
'The Cambridge History of Southeast Asia', in K. M. de Silva et al, eds. Asian Panorama, Delhi: Vikas, 1990, pp. 558-61.

"'Ah-Ah": Britain and the Bandung Conference of 1955', Journal of Southeast Asian Studies, 23, 1 (March 1992), pp. 74-111.

'Brooke Rule in Sarawak and Its Principles', Journal of the Malaysian Branch of the Royal Asiatic Society, 65 (1992), pp. 15-26.

'Mercantilists and Missionaries: Impact and Accommodation'; 'Free-Trade Commercialism. Tradition under Pressure'; 'Intensive Capitalism: The Domination of Asian Societies' in Colin Mackerras, ed., Eastern Asia An Introductory History, Melbourne: Longman Cheshire, 1992, pp. 132-66.

'The Establishment of the Colonial Regimes', in N. Tarling, ed., The Cambridge History of Southeast Asia, Cambridge: Cambridge University Press, 1992, II, pp. 5-78.

'The World Wars and the British in Southeast Asia', New Zealand Journal of History, 27, 1 (April 1993), pp. 3-15.

'Miss Upcott Not At Home', Khabar Seberang, 23 (1992), pp. 105-22.

'New Zealand, ASIA 2000 and Beyond', New Zealand Journal International Review, 19, 3 (May-June 1994), pp. 20-22.

"'The First Pharos of the Eastern Seas": The Construction of the Horsburgh Lighthouse on Pedra Branca', Journal of the Malaysian Branch of the Royal Asiatic Society, 67, 1 (June 1994), pp. 1-8.

'The Brookes and the British Government', in Victor T. King and A. V. M. Horton, eds., From Buckfast to Borneo. Essays presented to Father Robert Nicholl on the 85th Anniversary of his Birth, University of Hull, 1995, pp. 253-9.

'Some Perspectives on Southeast Asian Historiography', Journal of the Malaysian Branch of the Royal Asiatic Society, 68, 2 (December 1995), pp. 53-57.

'Word-Watching: "Slip, Slide, Perish"', in Michael Peters, ed., Cultural Politics and the University in Aotearoa / New Zealand, Palmerston North: Dunmore, 1997, pp. 89102.

'The British Empire in South-East Asia', in Robin W. Winks, ed., The Oxford History of the British Empire, vol. 5 Historiography, Oxford University Press, 1999, V, pp. 403-15.

'Indonesia After Soeharto', in Indonesia After Soeharto, Auckland: New Zealand Asia Institute, University of Auckland, 1999, pp. 11-14.

"'Cold Storage": British Policy and the Beginnings of the Irian Barat / West New Guinea Dispute', Australian Journal of Politics and History, 46, 2 (June 2000), pp. 175-93.

'The British and the Kuomintang Troops in Burma, 1950-1952', New Zealand Journal of Asian Studies, 2, 1 (June 2000), pp. 40-64.

'Imperialism and State-Building in Southeast Asia', The Eleventh James C. Jackson Memorial Lecture, 5 July 2000, Malaysia Society Asian Studies Association of Australia, 2000.

'Sabah under Chartered Company Rule'; 'The Labuan Entrepot and the Borneo Protectorate', in Cheah Boon Kheng, ed., Early Modern History, vol. 7 of The Encyclopedia of Malaysia, Singapore: Archipelago Press, 2001, pp. 104-7.

'Suharto: Father of Development?', Review Article, New Zealand Journal of Asian Studies, 2, 2 (December 2002), pp. 183-92.

'The Japanese Occupation of Southeast Asia', Sejarah, 9 (2001), pp. 1-19. 
'Aung San and Burma (Myanmar) Fifty Years On', Southeast Asia: A Multidisciplinary Journal (Brunei), 3 (1 \& 2) (2001/2002), pp. 65-70.

'British Attitudes and Policies on Nationalism and Regionalism', in Marc Frey, Ronald W. Pruessen and Tan Tai Yong, eds., The Transformation of Southeast Asia. International Perspectives on Decolonization, Armonk: M. E. Sharpe, 2003, pp. 127-41.

'Sir Keith Sinclair', in N. Tarling, ed., Auckland Minds and Matters, University of Auckland, 2003, pp. 155-65.

'Sabah, Brunei, Sarawak: An Imperial Legacy', in Ahmat Adam and Law Yew Meng, eds., IAHA 2000 Proceedings of the 16th Conference of the International Association of Historians of Asia, Kota Kinabalu: Universiti Malaysia Sabah, 2003, pp. 173-83.

'The British and the Kuomintang Troops in Burma', Jurnal Kinabalu, 9 (2003), pp. 1-19.

'Ambon (Amboina / Amboyna) Massacre (1623)'; 'Anglo-Dutch relations in Southeast Asia (Seventeenth to Twentieth Centuries)'; 'British Interests in Southeast Asia'; 'Colonialism'; 'Dutch Interests in Southeast Asia from 1800'; 'Free Trade'; 'Geneva Conference (1954)'; 'Germans (Germany)'; 'Great War (1914-1918)'; 'Imperialism'; 'Korean War (1959-1954)'; 'Piracy'; 'Tobacco'; '"White Man's Burden"', in Ooi Keat Gin, ed., Southeast Asia: A Historical Encyclopedia from Angkor Wat to East Timor, 3 vols., Santa Barbara: ABC-Clio, 2004.

'The Historians of Southeast Asia', in Andrew T. H. Tan, Michael L. R. Smith and Khoo Kay Kim, eds., Seeking Alternative Perspectives of Southeast Asia, Ipoh: Perak Academy, 2004, pp. 33-51.

'Corruption', in N. Tarling, ed., Corruption and Good Governance in Asia, Abingdon: Routledge, 2005, pp. 5-18.

(with Richard Phillips) 'The Founding of NZASIA', New Zealand Journal of Asian Studies, 7, 1 (June 2005), pp. 5-14.

'The Impact of the Korean War on Southeast Asia', in Richard Mason and Abu Talib Ahmad, eds., Reflections on Southeast Asian History since 1945, Penang: Penerbit Universiti Sains Malaysia, 2006, pp. 94-108.

\title{
Academic Reviews
}

\author{
American Historical Review \\ Asia Pacific Business Review \\ Asian Libraries \\ Asian Studies Association of Australia (ASAA) Review \\ Australian Journal of Politics and History \\ Comment \\ Historical Studies \\ Journal of Imperial and Commonwealth History \\ Journal of Oriental Studies \\ Journal of Southeast Asian Studies \\ Journal of the Polynesian Society \\ Journal of the Royal Asiatic Society \\ Journal of Siam Society \\ New Zealand Journal of History \\ Pacific Affairs
}


Pacific Historical Review

Pacific Viewpoint

Philippine Studies

Public Administration

The Historical Journal

The International History Review

The Journal of Developing Areas

\section{Other Publications}

'Is Australia Still An Outpost?' Meanjin, 21, 2 (1962), pp. 204-09. Reprinted in German in Theater und Zeit (Cologne), 4 (January 1963), pp. 92-95.

'Towards the Seventies', The University of Auckland Gazette, 10, 2 (November 1968), pp. $2-4$.

(with Olive Johnson) Cautions and Diversions, with cartoons by Lino Palacio, Auckland: authors, 1975.

'Eunice Hanger', in E. Hanger, 2D and Other Plays, ed., Alrene Sykes, St Lucia: University of Queensland Press, 1978.

'New Challenges for Old Students', New Zealand Journal of Adult Learning, 19, 1 \& 2 (May / October 1987), pp. 59-62.

'Is there A Political Role for Universities?' in What Can We Do for Our Countries? London: Association of Commonwealth Universities (ACU), 1988, pp. 68-74.

Addresses delivered at the Convocations for the Conferment of Honorary Degrees 19861992, University of Auckland, 1992.

New Zealand entry in Commonwealth Universities Yearbook, 1993-7.

The Essential Pocket Kiwi, Palmerston North: Dunmore, 1995.

\section{Programme Notes}

Tosca (Auckland Opera Trust, 1973)

Madam Butterfly (Northern Opera, 1976)

Aida (Symphonia, 1978)

Cavalleria Rusticana (Opera Production Trust, 1978)

Madam Butterfly (National Opera / Mercury Partnership, 1983)

The Elixir of Love (National Opera / Mercury Partnership, 1983)

The Italian Girl in Algiers (National Opera / Mercury Partnership, 1983)

Rigoletto (Mercury Opera, 1984)

Manon Lescaut (Mercury Opera, 1984)

Carmen (Mercury Opera, 1985)

Tosca (Mercury Opera, 1985)

La Traviata (Mercury Opera, 1986)

Lucia di Lammermoor (Mercury Opera, 1988)

Madam Butterfly (Mercury Opera, 1988)

Faust (Mercury Opera, 1989)

Don Giovanni (Mercury Opera, 1989)

Turandot (Mercury Opera, 1990) 
The Barber of Seville (Mercury Opera, 1990)

Le Nozze di Figaro (Mercury / Auckland Metropolitan Opera, 1991)

La Boheme (Aotea Centre, 1991)

The Pearl Fishers (Auckland Opera, 1992)

The Flying Dutchman (Auckland Opera, 1992)

Carmen (Auckland Opera, 1993)

The Magic Flute (Auckland Opera, 1993)

Petit Messe Solennelle (Auckland University Singers, 1993)

Madam Butterfly (Auckland Opera, 1994)

Rigoletto (Auckland Opera, 1994)

The Magic Flute (West Australian Opera, 1994)

Carmen (Canterbury Opera, 1994)

Faust (Auckland Opera, 1995)

Otello (Canterbury Opera, 1995)

The Magic Flute (Opera Queensland, 1995)

Don Giovanni (Opera New Zealand, 1996)

Turandot (Opera New Zealand, 1997)

II Trovatore (Opera New Zealand, 1997)

La Cenerentola (Opera New Zealand, 1998)

Verdi's Requiem (Opera New Zealand, 1998)

Macbeth (Opera New Zealand, 1998)

La Boheme (Opera New Zealand, 1999)

Cavalleria Rusticana and Paglliacci (Opera New Zealand, 1999)

Madam Butterfly (NBR New Zealand Opera, 2000)

Falstaff (NBR New Zealand Opera, 2001)

La Clemenza di Tito (Auckland Chamber Orchestra, 2001)

The Pearl Fishers (NBR New Zealand Opera, 2002)

Orfeo e Euridice (Auckland Chamber Orchestra, 2002)

Lakme (Canterbury Opera, 2003)

Tosca (NBR New Zealand Opera, 2003)

Rigoletto (NBR New Zealand Opera, 2004)

La forza del destino (Canterbury Opera, 2004)

Le Comte Ory (Canterbury Opera, 2004)

La Traviata (NBR New Zealand Opera, 2005)

Pagliacci (Canterbury Opera, 2005)

Suor Angelica (Canterbury Opera, 2005)

Lucia di Lammermoor (Canterbury Opera, 2006)

Faust (NBR New Zealand Opera, 2005)

Programme Notes (Auckland Philhamonia, 2007)

\section{Reviews of Theatrical Events}

Opera (London)

Opera Australasia, presently known as Opera-Opera (Sydney)

Theatre Australasia (Sydney)

New Zealand Opera News (Wellington) 


\section{Stage Performances by Nicholas Tarling}

Nick is versatile on the stage appearing and taking on a variety of roles. His stage debut was as Nikola in Arms and the Man performed at St Albans School. He has not looked back since then as the following listing reveals his prowess as an actor. Forgive some missing information as they receded over time. (Venue is in parentheses.)

1947 Nikola in Arms and the Man (St Albans School)

1949 Maitre Jacques in L'avare (St Albans School)

1961 Porter in Macbeth (Twelfth Night Theatre [TNT], Brisbane)

Husband in Foundations (TNT)

Young Pitt in Vanity Fair (TNT)

Christmas Revue (TNT)

1962 Posket in The Magistrate (TNT)

Magistrate in Lysistrata (TNT)

Lear and Gloucester in Lear (TNT)

Bosola in The Duchess of Malfi (University of Queensland Staff Players [UQSP])

Dan in The Beautiful People (TNT)

Peter in Colonial Experience (TNT)

Parson in Shipwreck (TNT)

First Relative in Ham Funeral (TNT at Her Majesty's Brisbane)

Abe in Desk Set (TNT)

1963 Schoolteacher in The Visit (TNT)

Fisherman in (and producer of) Pirates at the Barn (TNT)

Premier in The Applecart (UQSP)

King Henry IV in Henry IV Part One (TNT)

Henry in The Wrong Side of the Park (TNT)

Garooh in Image in the Clay (Abschol, University of Queensland)

Doctor in Cradle Song (TNT)

Argan in The Imaginary Invalid (TNT)

1964 Pochet in Keep Your Eye on Amelia (TNT)

1965 Lionel in See How They Run (TNT)

Sir Oliver in School for Scandal (Auckland University Theatre Company [AUTC])

Typist in The Typist and the Tigers (Central Theatre, Auckland)

Doctor in Treasure (Central Theatre, Auckland)

Simeon in York Nativity (Theatre Guild in St Mary's Cathedral)

1966 Producer of Vaughan William's opera Riders to the Sea (AUTC)

Revue, Short Back and Sides (Auckland University 5 and 9 Club [5 \& 9])

Man in The House by the Stable (Remuera Players)

Judge in The Noble Spaniard (Remuera Players)

1967 Bitos in Poor Bitos (AUTC)

Revue, Once Over Lightly (5 \& 9)

Poppa in The Shifting Heart (Remuera Players)

Bishop in See How They Run (Remuera Players) 
Scrooge in Scrooge the Miser (Remuera Players)

Villain in Hiss the Villain (Remuera Players)

1968 Revue, Half A Mo (5 \& 9)

Bapista in (and producer of) The Taming of the Shrew (Auckland University

Outdoor Shakespeare)

Maurice in The House by the Lake (Remuera Players)

Charles in Blithe Spirit (Remuera Players)

Man in The Second Step (Remuera Players)

1969 John of Gaunt in Richard II (Auckland University Outdoor Shakespeare)

Revue, Was 1969 Really Necessary? (5 \& 9)

Major and MP in Separate Tables (Remuera Players)

1970 Trial and Error (Remuera Players)

1971 Philip in Relatively Speaking (Remuera Players)

The Secret Tent (Remuera Players)

1972 Husband in How She Lied to Her Husband (Remuera Players)

Crocker-Harris in The Browning Version (Remuera Players)

Two Dozen Red Roses (Remuera Players)

1973 Jim Preston in Woman in a Dressing Gown (Remuera Players)

Dedication Play (Holy Trinity Cathedral)

Nativity Play (Remuera Players)

1974 Cassius in Julius Caesar (Auckland University Outdoor Shakespeare)

Farmer in The Farm (Central Theatre, Auckland)

Hugh Latymer in A Song at Twilight (Remuera Players)

1975 Various parts in The Great War (New Independent Theatre)

1976 Iago in Othello (Auckland University Outdoor Shakespeare)

Milkman and Brewster in Roses Round the Door (Remuera Players)

Revue, Laying Ourselves Wide Open (Auckland University Theatre Workshop)

Ed Devery in Born Yesterday (New Independent Theatre)

1977 Shylock in The Merchant of Venice (Auckland University Theatre Workshop)

Capping Revue (Maidment Arts Centre)

Estragon in Waiting for Godot (Auckland University Theatre Workshop)

1978 Friar Lawrence in Romeo and Juliet (Auckland University Outdoor Shakespeare)

Capping Revue (Maidment Arts Centre)

Scrub in Beaux Stratagem (Auckland University Outdoor Shakespeare)

Herod in Salome (Auckland University Outdoor Shakespeare)

Narrator, Bluebeard (Opera and Ballet Workshop)

Narrator, Aida (Symphonia of Auckland)

More in A Man For All Seasons (Howick Little Theatre)

A Touch of Tinsel, reader and compiler (various venues)

1979 Polonius in Hamlet (Auckland University Outdoor Shakespeare)

King of Hell in Release from Hell, Noh Play (3rd New Zealand Asia Association [NZASIA] Conference)

Look at the Trees, reader and compiler (various venues)

Sir Epicure Mammon in The Alchemist (Auckland University Theatre Workshop)

1980 A Moment in Time, reader and compiler (various venues)

Revue, The 1980 Flower Show (Maidment Arts Centre) 
Lear in Shakespeare at Court (Auckland University Theatre Workshop) After Magritte (Auckland University Theatre Workshop)

Moon in The Real Inspector Hound (Auckland University Theatre Workshop)

Morgenhall in Dock Brief (New Independent Theatre)

Another Touch of Tinsel (various venues)

1981 Revue, Listen 'ere (Maidment Arts Centre)

Tramp in The Caretaker (Arena Theatre)

Newton in Mr Wilberforce M. P. (Pilgrim Productions, Centennial Theatre)

Pinchard in Sauce for the Gander (Mercury Theatre)

Jim Stokes in The Great 1979 National Strike (Mercury Workshop)

Reader in Douglas Mews' Table Talk (New Zealand Symphony Orchestra Cushion Concert)

1982 Frank Foster in How the Other Half Loves (Arena Theatre)

Porter in Macbeth (Auckland University Outdoor Shakespeare)

Sir Charles Marlow in She Stoops to Conquer (Mercury Theatre)

Revue (Maidment Arts Centre)

A Further Touch of Tinsel (various venues)

1983 Hastings in Richard III (Auckland University Outdoor Shakespeare)

Parson Manders in Ghosts (New Independent Theatre)

Who and What Are You?, compiler and reader (Genealogists Conference, Hamilton)

Number 11 in 12 Angry Men (Arena Theatre)

Christmas Readings (Holy Trinity Cathedral)

1984 Reg in Table Manners (Arena Theatre)

More in A Man for All Seasons (Arena Theatre)

Revue, The Umpire Strikes Back (Maidment Arts Centre)

Coulmier in Marat/Sade (Auckland University Theatre Workshop)

Dr Bradman in Blithe Spirit (Arena Theatre)

1985 Roat in Wait Until Dark (Arena Theatre)

Chasuble in The Importance of Being Earnest (Arena Theatre)

Freedom's Fancy, reader and compiler (Amnesty)

PM and Harcourt in Tomorrow Will Be A Lovely Day (Arena Theatre)

A Touch More Tinsel (Holy Trinity Cathedral)

1986 Dr Rank in Doll's House (Arena Theatre)

Colonel in Journey's End (Arena Theatre)

Owner in Mal de Mer, opera by G. Seaman (Keys Memorial Concert, Centennial Theatre)

In Flanders' Fields, compiler and reader (Arena Theatre and elsewhere)

Colonel Pickering in Pygmalion (Arena Theatre)

Baron Hardupp in Cinderella (Maidment Arts Centre)

Organ Recital (Holy Trinity Cathedral)

Softcops (Auckland University Theatre Workshop)

1987 East and West, compiler and reader (7th NZASIA Conference)

Sir in The Dresser (Howick Little Theatre)

Christmas Readings (Holy Trinity Cathedral)

1988 The Victorians, compiler and reader (Auckland University Elderhostel and many reps) 
Where Is Your Kingdom Now? (Howick Little Theatre)

1989 Christmas Readings (Holy Trinity Cathedral)

1990 Monsewer in The Hostage (Devonport Theatre Company)

A Sort of Music Hall, performer, compiler and producer (Devonport Theatre Company)

1991 Bullshot Crummond (Devonport Theatre Company) Mozart, Man and Musician, compiler and reader (Aotea Centre and elsewhere)

1992 Jupiter Rossini-Divine Master, compiler and reader (Aotea Centre and elsewhere) Husband in Your Bed or Mine (Devonport Theatre Company) Shallow in The Merry Wives of Windsor (Pumphouse) Loot (Devonport Theatre Company)

1993 Annas in The Crucifixion (Cyrano Productions / Howick Little Theatre) Tchaikovsky, Man and Musician, compiler and reader (Aotea Centre and elsewhere) C. S. Lewis in Shadowlands (Howick Little Theatre)

1994 Such Beautiful Melodies: A Programme about Robert Schumann, compiler and reader (Aotea Centre)

1996 Giles in The Crucible (Auckland University Theatre Workshop)

2001 Harper in Arsenic and Old Lace (Company Theatre) 